\title{
Influence of temperature, salinity, and oxygen on the cadmium balance of mussels Mytilus edulis
}

\author{
Helmut Fischer
}

Institut für Meereskunde an der Universität Kiel, Düsternbrooker Weg 20, 2300 Kiel 1, Federal Republic of Germany

\begin{abstract}
Juvenile mussels Mytilus edulis L. were cultivated in controlled flow-through aquaria to investigate the influence of environmental temperature, salinity, and dissolved oxygen on cadmium balance. (1) Inverse relations between $\mathrm{Cd}$ concentration of soft tissues and physical condition of mussels were observed in response to temperature. The relation between $\mathrm{Cd}$ body burden and shell weight (Cd/shell-wt index) is independent of temperature between 7 and $25^{\circ} \mathrm{C}$. (2) Reducing salinity $\left(\mathrm{mg} \mathrm{kg}^{-1}\right)$, while keeping dissolved $\mathrm{Cd}\left(\mu \mathrm{g} \mathrm{l}^{-1}\right)$ constant, increases the molar ratio of $\mathrm{Cd}$ and seawater salts. Accumulation of $\mathrm{Cd}$ in the soft tissues and of $\mathrm{Ca}$ in the shells of mussels is determined by $\mathrm{Cd}$ and $\mathrm{Ca}$ concentrations within the range of 15 to $30 \%$ salinity. Residues of $\mathrm{Cd}$ in mussels, therefore, are higher in samples from lower salinity. Below $15 \%$ the $\mathrm{Cd} / \mathrm{shell}$-wt index is disproportionately higher, corresponding to reduced shell growth in lower salinities. Slightly lower index values were observed in $35 \%$. (3) Dissolved oxygen concentrations between 2.5 and $6.5 \mathrm{ml} \mathrm{l}^{-1}$ have no influence on the Cd balance of mussels. (4) Experimental results were reproducible and corresponded to field observations. (5) Modifications of growth and performance were in accordance with the literature. Lowest experimental temperature, salinity, and oxygen tested inhibited both growth of mussels and Cd uptake within a small laboratory gradient. Growth in the concerned environment is discussed as an essential aspect of research on metals and molluscs, and in relation to the mussel watch concept.
\end{abstract}

\section{INTRODUCTION}

Mussels (Mytilus edulis and related species) have been suggested for monitoring of coastal water quality on a global scale. Numerous 'mussel watch' (Goldberg 1975) projects have confirmed increases in contaminant levels in mussels from industrialized shores. Numerous laboratory studies have documented the molluscan capacity of bio-concentrating aquatic contaminants (reviews: Phillips 1980, Eisler 1981). Using mussels as biological indicators has entered national and international administrative programmes in marine pollution control (USA: Stephenson et al. 1979, Goldberg et al. 1983; North Atlantic: ICES 1982; North Sea: BMI 1986).

When the biological content indicator concept evolved from empirical evidence, molluscs may have been envisaged as a type of self-maintaining ion exchange device - a substitute which could help to overcome difficulties in seawater chemistry. A decade of research, however, has discovered considerable problems when evaluating mussel watch data. The effort spent in this matter (Bryan 1980, review) suggests that comparable difficulties would have been found in other organisms if they had been investigated as intensively. Mussels respond to a large variety of external stimuli. Phillips (1976) developed sampling strategies to eliminate the influence of some environmental variables on metal concentrations in mussels. Sexual maturation has been identified as a source of biological variability (Cossa et al. 1979, Orren et al. 1980). Some new alternative suggestions are based on models in metal biochemistry (Zaroogian 1980, Simkiss \& Taylor 1981).

When using organisms as indicators of contaminants, biological variability must be recognized. This can be a matter of choosing an appropriate independent variable. Recently the accumulation of cadmium has been interpreted as a result of organismic immobilisation, and shell weight has been chosen as a correlate of similar cumulative character. The influence of individual size, spawning, food supply, and tidal exposure could be eliminated from mussel watch programmes by introducing shell weight as an independent variable in relation to the amount of cadmium in soft tissues ( $\mathrm{Cd} /$ shell-wt index, Fischer 1983; Table 1). The former study resulted from a methodological field survey. Apart from describing an experimental verifi- 
cation of a new approach, the work reported here provides information on the influence of temperature, salinity, and dissolved oxygen on the cadmium balance of mussels. Methodological aspects relate to the scaling of laboratory studies on the accumuiation of metals by molluscs, and to growth as an essential aspect in the mussel watch concept.

Table 1. Mytilus edulis. Cadmium balance of field-collected samples. Where the $\mathrm{Cd}$ concentration of soft tissues varies depending on physical condition, the $\mathrm{Cd} /$ shell-wt index is not affected (abstracted from Fischer 1983)

\begin{tabular}{|lcccc|}
\hline \multicolumn{1}{|l}{ Mussels are } & Cd in meat & & Meat weight & Cd in meat \\
& Meat weight & Shell weight & Shell weight \\
\hline $\begin{array}{l}\text { Very young } \\
\text { Very old }\end{array}$ & & & \\
Starved & Increased & Decreased & Not affected \\
Spawned & & & \\
Tidally exposed & & \\
\hline
\end{tabular}

\section{MATERIAL AND METHODS (GENERAL)}

\section{Laboratory cultivation}

Juvenile blue mussels Mytilus edulis L. of approximately $7 \mathrm{~mm}$ shell length (experiment on influence of temperature: 3 to $4 \mathrm{~mm}$ ) were collected from their natural habitat in Kieler Förde, Western Baltic Sea. They were kept in a series of flow-through aquaria and fed a chemostat algal culture. Experimental water and feed algae were introduced with a peristaltic pump. Filtration rates of juveniles as reported by Riisgård et al. (1980) were used to scale the experimental flow rates. Unless being controlled at intervals as experimental variables, standard environmental conditions were as follows: temperature, $15^{\circ} \mathrm{C}$; salinity, $15 \%$; dissolved oxygen, air saturated, i.e. $6.5 \mathrm{ml} \mathrm{l}^{-1}$; dissolved $\mathrm{Cd}_{1} 1 \mu \mathrm{g} \mathrm{l}^{-1}$ added to the natural concentration of approximately $0.1 \mu \mathrm{g} \mathrm{l}^{-1}$. The experiments were terminated after 9 to $20 \mathrm{wk}$, according to the observed growth.

Water supply. Natural seawater (salinity 16 to $19 \%$ ) was pumped from a depth of $4 \mathrm{~m}$ in Kieler Förde with all-plastic pumps, passed through $20 \mathrm{~mm}$ mesh, and stored in polyethylene containers until use. Experimental water was prepared by adjusting salinity to $15 \%$ (Kieler Förde annual average for surface water) with distilled water. $\mathrm{Cd}$ was added as $\mathrm{CdCl}_{2}$. Results of $\mathrm{Cd}$ water analysis were not significantly different from calculated $\mathrm{Cd}$ concentrations. A radiotracer experiment showed that virtually all $(97 \%)$ added $C d$ was in the 'dissolved' $(<0.4 \mu \mathrm{m})$ phase.

Algal culture. The green coccal alga Nannochloris sp. was used because of its resistance to large differences of salinity (cf. Witt et al. 1981). Algal culture water was prepared after Betz (1977) with analytical grade chemicais: $100 \mathrm{mg} \mathrm{l}^{-1} \mathrm{NaNO}_{3}, 20 \mathrm{mg} \mathrm{l}^{-1}$ $\mathrm{Na}_{2} \mathrm{HPO}_{4}, 80 \mathrm{mg} \mathrm{l} \mathrm{l}^{-1} \mathrm{NaHCO}_{3}$, and $2 \mathrm{mg} \mathrm{l^{-1 }} \mathrm{FeCl}_{3}$ $\cdot 6 \mathrm{H}_{2} \mathrm{O}$. The use of EDTA was strictly avoided. Illumination was by fluorescent tube lights in a $20 \mathrm{~h} \mathrm{light} / 4 \mathrm{~h}$ dark cycle.

Dimensions. Ten juvenile mussels were each attached to perspex supports and suspended in aerated flow-through aquaria with a volume of $600 \mathrm{ml}$. The daily water exchange was approximately 600 (start) to $1200 \mathrm{ml}$ plus 60 to $120 \mathrm{ml}$ of algal suspension. The volume of the chemostat culture was adjusted to give a daily renewal of approximately $20 \%$.

Experimental routine. At weekly or biweekly intervals the length of individual mussels was measured by a calibrated ocular micrometer in a stereo microscope. Pooled live weights were determined. Temperature and dissolved oxygen were measured directly; salinity was measured or calculated from flow rates of peristaltic pumps. New algal batch cultures were inoculated every month and used in the chemostat after $14 \mathrm{~d}$.

\section{Analytical steps}

Before sample preparation and analysis, juvenile mussels were kept for $1 \mathrm{~d}$ without food to allow elimination of gut contents. Mussels were killed by wet heat at $60^{\circ} \mathrm{C}$, detached from their supports, and soft tissues were removed from the valves. Shells were dried overnight, weighed, and measured for length. Individual soft tissues were freeze-dried, oven-dried at $100^{\circ} \mathrm{C}$ for $2 \mathrm{~h}$, and weighed. Digestion was carried out in quartz test tubes, with loose teflon lids, by a 1:1 mixture of concentrated nitric and perchloric acids for $2 \mathrm{~h}$ at $90^{\circ} \mathrm{C}$. The samples were diluted with distilled water and analysed for $\mathrm{Cd}$ by flameless AAS. Subsamples of $20 \mathrm{mg}$ of reference material TORT-1 (available from the National Research Council, Ottawa, Canada) were analysed for quality control.

\section{Calculations}

All data refer to the dry weight of soft tissues and shells. Outliers $\left(\left|\bar{x}-x_{1}\right|>3\right.$ SD) were eliminated. Error terms in comparisons relate to the $95 \%$ confidence intervals of means.

Individual growth increments were estimated basing on initial shell length and the relations

$$
\begin{aligned}
& \text { shell wt }=a \text { shell length } \\
& \text { meat wt }=b \text { shell wt }
\end{aligned}
$$


The coefficients were determined in subsamples before starting the experiments. The exponent of 2.85 was determined empirically from a large number of individual measurements. Reverse calculations produced deviations not greater than $\pm 5 \%$.

Constants of daily growth, $k$, were determined from measured final weight data and calculated initial weight (Eq. 1\&2), using the formula

$$
W=W_{0} e^{k t}
$$

Growth constants depend on individual size (review: Jörgensen 1976), a problem eliminated here by conducting experiments with juveniles of similar size.

A condition index (CI) of mussels was calculated in terms of $\%$ soft tissue weight of total dry weight:

$$
\mathrm{CI}=\frac{\text { soft tissue dry wt }}{\text { total dry wt }} \cdot 100
$$

\section{CONTROLLED CULTIVATION EXPERIMENTS}

\section{Temperature}

\section{Experimental techniques}

Temperature was preset at $5 \mathrm{C}^{\circ}$ intervals between 5 and $25^{\circ} \mathrm{C}$ by placing the flow-through aquaria in controlled water baths. Thermometer readings were recorded every week. Constancy was within $\pm 0.2 \mathrm{C}^{\circ}$.

Temperature influences growth of mussels, which results in changing food requirements. Equivalent nutrition was approximated by maintaining a high rate of water and food supply. Differences in growth were allowed for by adjusting flow rates to the pooled live weight of mussels in each aquarium. Seventy-five $\%$ of

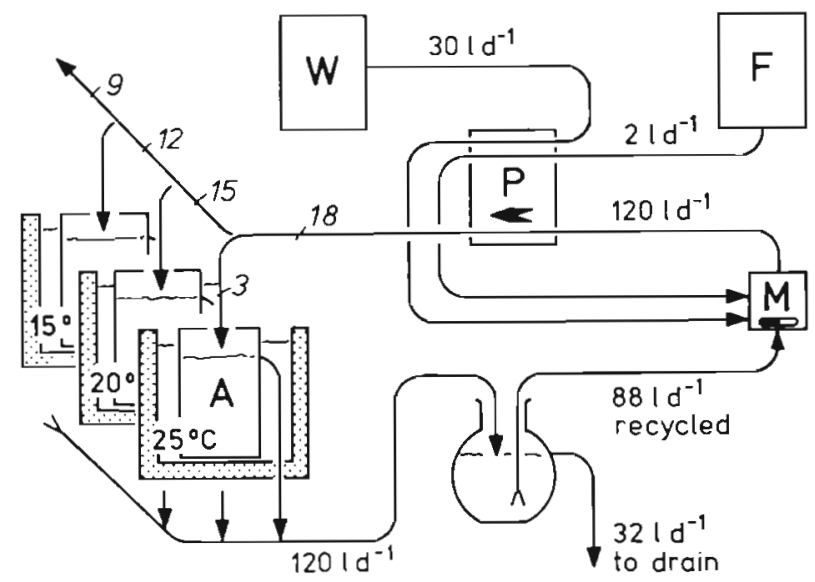

Fig. 1. Flow-through system for testing effects of temperature. W: water; F: feed algae; P: peristaltic pump; $\mathrm{M}$ : mixing cell; A: series of thermostated aquaria. Some flow-rates are given experimental water was recirculated. A scheme of experimental arrangements is given in Fig. 1.

Results

\section{Cadmium balance}

$C d$ concentration of soft tissues. Chemical analyses of soft tissues showed that $\mathrm{Cd}$ concentration in soft parts was highest in mussels grown at $25^{\circ} \mathrm{C}$ (Fig. 2a). Maximum dry tissue concentrations exceeded $80 \mu \mathrm{g}$ $\mathrm{g}^{-1}$. Lowest tissue concentrations were approximately $35 \mu \mathrm{g} \mathrm{g}^{-1}$ in mussels grown at 7 and $11^{\circ} \mathrm{C}$.

Condition index. The reverse relation was observed in the physical condition of mussels. The CI was $20 \%$ in mussels from $7{ }^{\circ} \mathrm{C}$, but those grown in $25^{\circ} \mathrm{C}$ exhibited only half that value.

$\mathrm{Cd} /$ shell-wt index. Relating $\mathrm{Cd}$ body burden with shell weight gave a mean of $8.2 \pm 1.1 \mu \mathrm{g} \mathrm{g}^{-1}$ over the range of experimental temperatures from 7 to $25^{\circ} \mathrm{C}$ (Fig. 2b, shaded).

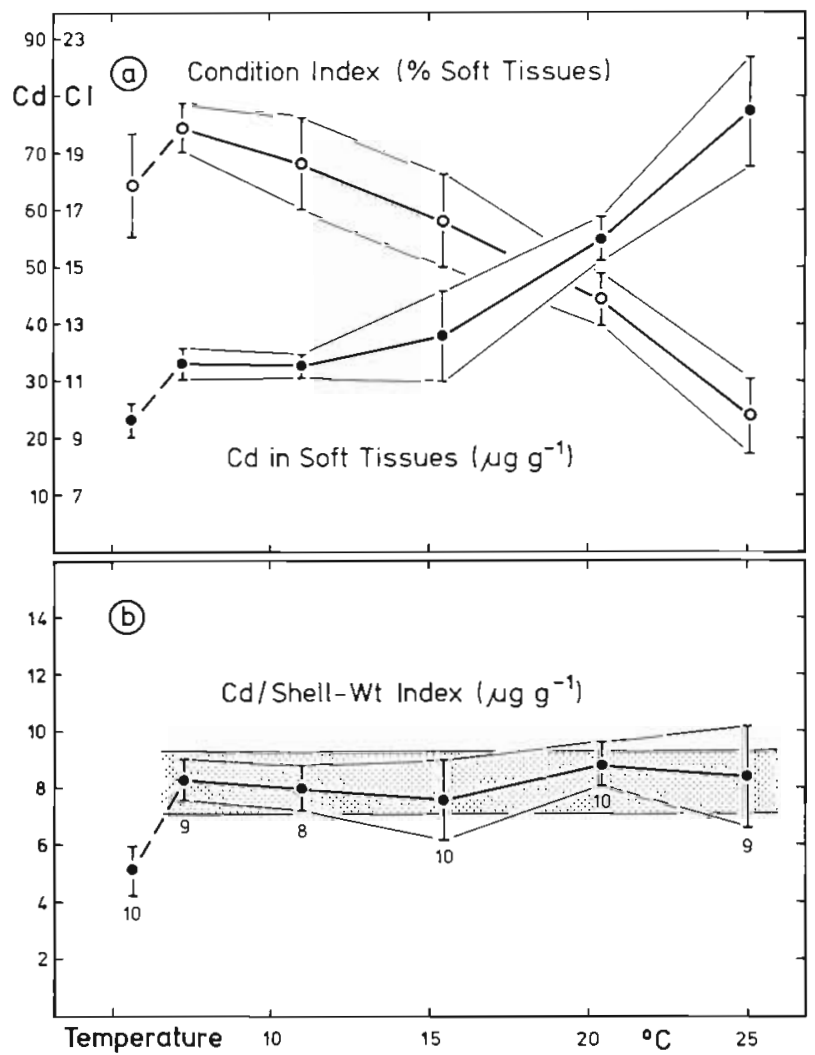

Fig. 2. Mytilus edulis. Influence of temperature on $\mathrm{Cd}$ balance (15\%; air-saturated $1.1 \mu \mathrm{g} \mathrm{Cd} \mathrm{l}^{-1}$ ). (a) Higher Cd concentrations in soft tissues and lower condition are found at elevated temperature. (b) The $\mathrm{Cd} /$ shell-wt index remains unaffected. $\mathrm{Cd}$ accumulation is inhibited in the lowest experimental temperature. Bars: $95 \%$ confidence intervals of means; shaded: common arithmetic mean 
Inconsistency. The results observed in mussels from $5.6^{\circ} \mathrm{C}$ was in remarkable contrast to this consistent pattern. Their $\mathrm{Cd}$ concentration, $\mathrm{Cl}$, and $\mathrm{Cd}$ /shell-wt index were considerably lower than the other data.

\section{Growth and performance}

The experiment was terminated after $8 \mathrm{wk}$. Within the range 7 to $25^{\circ} \mathrm{C}$ the increase in pooled live weights (in terms of the constant of daily growth) was lowest at the lowest temperature (Table 2). Maximum growth was observed at $15.4^{\circ} \mathrm{C}$. At higher temperatures mean growth declined. Ten \% mortality occurred at $25^{\circ} \mathrm{C}$ though the majority of individuals continued to grow at this highest experimental temperature. Modifications of shell proportions were not observed except in the juveniles grown at $15^{\circ} \mathrm{C}$. Their valves appeared to be flatter, but variability was substantial and differences were not significant. Length-normalized shell weight was used as an indicator of thin (lightweight) shells when environmental variables promote the growth of mussels. The allometric equation $\mathrm{W}=a \mathrm{~L}^{285}$ was applied, and the data were normalized to a shell length of $10 \mathrm{~mm}$.

\section{Discussion}

Temperature is estimated to be a major environmental variable influencing cadmium in molluscs (reviews: Phillips 1980, Eisler 1981). Experimental studies in general have been short-termed. They provide no information on a final equilibrated state. There are no field observations concerning effects of temperature on $\mathrm{Cd}$ balance of mussels.

Apart from its descriptive character, this experiment was designed to provide a verification of the $\mathrm{Cd} / \mathrm{shell}$ wt index as a reliable indicator of environmental $\mathrm{Cd}$. The conceptual frame was as follows. (1) A rise in temperature accelerates life processes in mussels including those of concern in the binding of $\mathrm{Cd}$ in soft tissues, and of calcium carbonate deposition in shells. (2) The higher the temperature the lower the net growth efficiency (cf. Bayne et al. 1973), which reduces growth of soft tissues. (3) Below the optimum, deposition of calcareous shells appears to be directly governed by temperature (cf. Mann 1979). Consequently, mussels grown at an elevated temperature were expected to be of a lower physical condition, and to exhibit higher $\mathrm{Cd}$ concentrations in their soft tissues. If the relation between soft-tissue $\mathrm{Cd}$ burden and shell weight was a reliable index of environmental $\mathrm{Cd}$, the $\mathrm{Cd} /$ shell-wt index should not be affected by temperature. This was verified between 7 and $25^{\circ} \mathrm{C}$ (Fig. 2).

The additional observations on growth and performance are in accordance with the findings of others. A growth optimum between 15 and $20^{\circ} \mathrm{C}$ has also been found by Coulthard (1929), Richards (1946), and Almada-Villela et al. (1982). Particle clearance follows a similar pattern (Theede 1963, Schulte 1975). The onset of mortality at $25^{\circ} \mathrm{C}$ (see also Mann \& Ryther 1977) can be attributed to a sharp decline in energy balance when temperature exceeds $20^{\circ} \mathrm{C}$ (Bayne et al. 1973). With respect to shell dimensions the experimental results reported here confirm field observations of mussels producing light (thin) shells when their growth rate is high. This has often been mentioned in connection with nutrition (e.g. Havinga 1929, Boje 1965, Seed 1968), but it seems to be a general interrelation - and vice versa: slow growth and heavy shells coincide in case of suboptimal or supraoptimal temperature (this study), tidal emersion and wave action (Baird \& Drinnan 1957, Harger 1970, 1971), or insufficient food supply (Fischer 1983).

With respect to the scope of this study these additional results are marginal. However, they provide information on the method applied and require consideration for this reason.

\section{Salinity}

\section{Experimental techniques}

This experiment was conducted with a constant ratio between dissolved $\mathrm{Cd}$ and natural seawater salts in a sequence of salinities (see Fig. 4). Cadmium (4.25

Table 2. Mytilus edulis. Influence of temperature on the growth constant $k$ of pooled live weight, and of length-normalized shell weight. Increased growth at the optimum experimental temperature concides with the formation of light shells $(95 \%$ confidence intervals of means)

\begin{tabular}{|c|c|c|c|c|c|}
\hline & \multicolumn{5}{|c|}{ Temperature $\left({ }^{\circ} \mathrm{C}\right)$} \\
\hline & 7.1 & 10.9 & 15.4 & 20.4 & 25.2 \\
\hline$k\left(\mathrm{~d}^{-1}\right)$ of live weight & 0.0060 & 0.0115 & 0.0308 & 0.0196 & 0.0095 \\
\hline Final shell-wt (mg) of $10 \mathrm{~mm}$ individuals & $34 \pm 3$ & $34 \pm 4$ & $26 \pm 3$ & $31 \pm 2$ & $37 \pm 4$ \\
\hline $\mathrm{n}$ & 15 & 15 & 15 & 15 & 15 \\
\hline
\end{tabular}




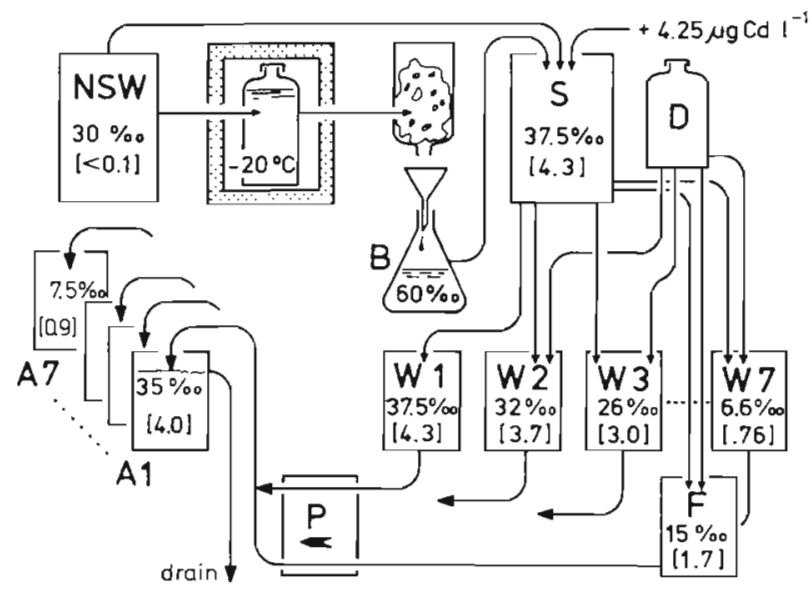

Fig. 3. Water supply and flow-through system for testing effects of salinity. NSW: North Sea water; B: brine; S: hypersaline stock; D: deionized water; W: water; F: feed algae; P: peristaltic pump; A: aquaria. Some salinities and Cd concentrations are given

$\left.\mu \mathrm{g} \mathrm{l}^{-1}\right)$ was added to hypersaline water $(37.5 \%$ ) which was then diluted with deionized water to give a number of experimental stocks. Further dilution with the feed algae suspension $\left(15 \% ; 1.7 \mu \mathrm{g} \mathrm{l}^{-1} \mathrm{Cd}\right)$ was by the multichannel peristaltic pump, which operated the flow-through arrangement (Fig. 3). Salinities of the experimental stock water were calculated from measured flow rates of water and algae, and adjusted to give desired final salinities between 7.5 and $35 \%$ in the flow-through aquaria. Final salinities were determined by density measurements, or calculated from measured flow rates. There were no significant differences between these methods. Variability was within $\pm 5 \%$ of the mean data.

The use of tap water for dilution was strictly avoided to exclude possible sources of contamination. For the same reason commercial seawater salt was not used. The hypersaline sea water was prepared from offshore North Sea water ( 30 to $32 \%$ ) by adding a brine (50 to $65 \%$ ) which had been separated from thawing North Sea water ice (cf. Fig. 3).

Juvenile mussels were collected in the field (16\% S sea water) and adapted at $5 \%$ intervals to experimental salinities over a period of $3 \mathrm{wk}$. Comparable growth in all salinities except the lowest showed that the juveniles were well adapted (cf. Bøhle 1972).

Results

\section{Cadmium balance}

Cd concentration of soft tissues. Cd concentrations were not significantly different in mussels grown in salinities between 10 and $35 \%$ (Fig. 4a). An average

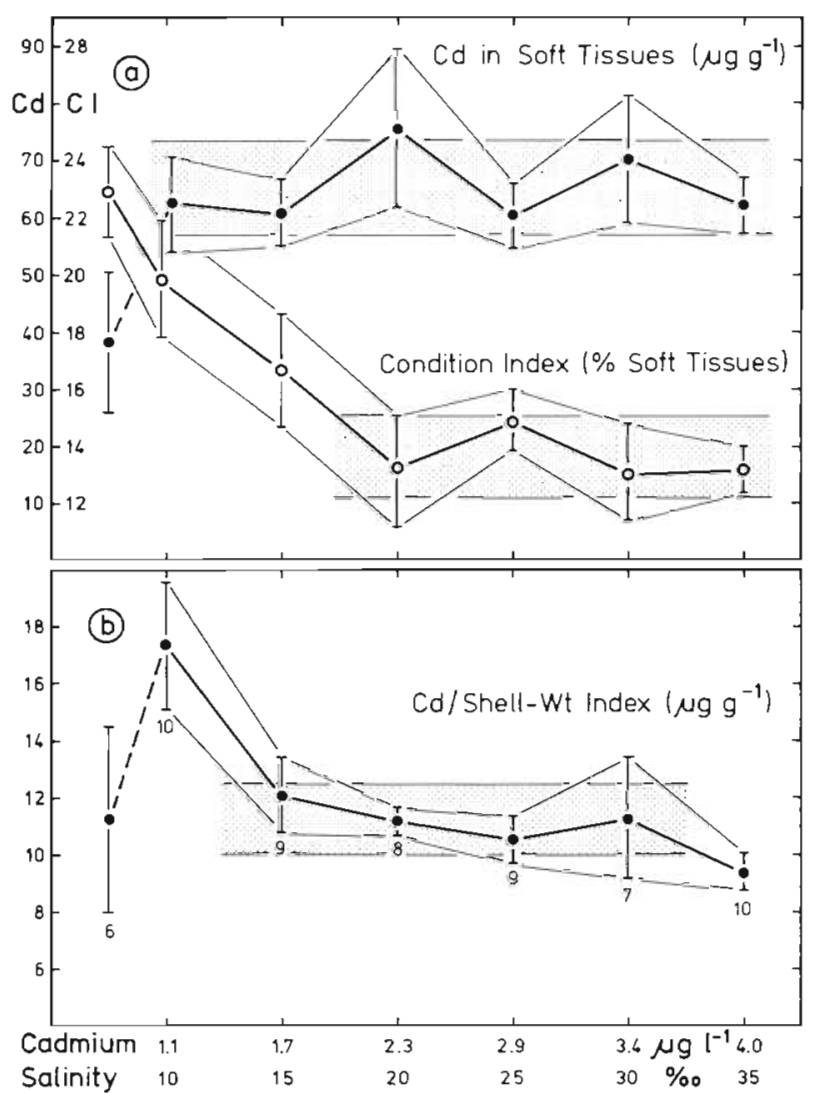

Fig. 4. Mytilus edulis. Influence of salinity on $\mathrm{Cd}$ balance; equimolar availability of $\mathrm{Cd}$ and seawater salts $\left(15^{\circ} \mathrm{C}\right.$; airsaturated; $4 \mu \mathrm{g} \mathrm{Cd} / 35 \mathrm{~g}$ seawater salts). (a) $\mathrm{Cd}$ concentration of soft tissues is independent of salinity. Condition increases in the lower salinities. (b) $\mathrm{Cd} /$ shell-wt index is independent of salinity between 15 and $30 \%$. Inhibition of Cd accumulation occurred in lowest experimental salinity. Bars: $95 \%$ confidence intervals of means; shaded: common arithmetic means

Cd concentration of $65 \pm 8 \mu \mathrm{g} \mathrm{g}{ }^{-1}$ corresponds to a constant ratio of $114 \mathrm{ng} \mathrm{Cd}$ per g natural seawater salts in the culture water, according to the experimental design.

Condition index. Independence of salinity was also observed in the CI which was $14 \pm 1.5 \%$ in mussels from 20 to $35 \%$. At lower salinities the CI increased and showed the highest experimental value, $23 \%$, in mussels from the lowest salinity.

$\mathrm{Cd} /$ shell-wt index. This index appeared to increase from 9.5 to 12 when salinity was reduced from 35 to $15 \%$. The trend, however, was not statistically significant due to high variability in the $30 \%$ results. A mean $\mathrm{Cd} /$ shell-wt index of $11.3 \pm 1.2 \mu \mathrm{g} \mathrm{g}^{-1}$ was calculated for mussels from 15 to $30 \%$ (Fig. $4 \mathrm{~b}$, shaded). The $\mathrm{Cd} /$ shell-wt index of mussels from $35 \%$ was some $15 \%$ lower. In mussels from $10 \%$ the $\mathrm{Cd} /$ shell-wt index was significantly higher.

Inconsistency. A lower tissue concentration and a 
Table 3. Mytilus edulis. Influence of salinity on daily growth constants $k$ of meat and shell weight, and on length-normalized shell weight. Growth and performance are constant over a wide range of salinities. Growth rates are markedly reduced below $10 \%$ (95\% confidence intervals of means)

\begin{tabular}{|c|c|c|c|c|c|c|c|}
\hline & 7.5 & 10 & 15 & $\begin{array}{l}\text { Salinity (\%o) } \\
\qquad 20\end{array}$ & 25 & 30 & 35 \\
\hline$k\left(\mathrm{~d}^{-1}\right)$ of meat weight & $\begin{array}{r}0.0235 \\
\pm \quad .0028\end{array}$ & $\begin{array}{r}0.0329 \\
\pm \quad .0074\end{array}$ & $\begin{array}{r}0.0367 \\
\pm \quad .0053\end{array}$ & $\begin{array}{r}0.0339 \\
\pm \quad .0073\end{array}$ & $\begin{array}{r}0.0317 \\
\pm \quad .0075\end{array}$ & $\begin{array}{r}0.0329 \\
\pm \quad .0043\end{array}$ & $\begin{array}{r}0.0290 \\
\pm \quad .0056\end{array}$ \\
\hline$k\left(\mathrm{~d}^{-1}\right)$ of shell weight & $\begin{array}{r}0.0143 \\
\pm \quad .0023\end{array}$ & $\begin{array}{r}0.0274 \\
\pm \quad .0047\end{array}$ & $\begin{array}{r}0.0331 \\
\pm \quad .0039\end{array}$ & $\begin{array}{r}0.0321 \\
\pm \quad .0104\end{array}$ & $\begin{array}{r}0.0310 \\
\pm \quad .0066\end{array}$ & $\begin{array}{r}0.0347 \\
+\quad .0047\end{array}$ & $\begin{array}{r}0.0305 \\
\pm \quad .0044\end{array}$ \\
\hline Weight (mg), $10 \mathrm{~mm}$ shells & $\begin{array}{r}33 \\
\pm \quad 5\end{array}$ & $\begin{array}{r}30 \\
\pm \quad 3\end{array}$ & $\begin{array}{r}32 \\
\pm \quad 6\end{array}$ & $\begin{array}{r}32 \\
\pm \quad 2\end{array}$ & $\begin{array}{r}29 \\
\pm \quad 4\end{array}$ & $\begin{array}{r}32 \\
\pm \quad 4\end{array}$ & $\begin{array}{r}29 \\
\pm \quad 3\end{array}$ \\
\hline $\mathrm{n}$ & 6 & 10 & 9 & 8 & 9 & 9 & 10 \\
\hline
\end{tabular}

reversed trend in the $\mathrm{Cd}$ /shell-wt index were observed in mussels from the lowest experimental salinity $(7.5 \%)$.

\section{Growth and performance}

The flow-through experiment was conducted over a period of $9 \mathrm{wk}$. As reflected by the constants of daily growth, there were only minor differences of soft-tissue growth at salinities between 10 and $30 \%$ (Table 3). A slightly lower growth rate was noted at $35 \%$, and a marked reduction was observed in $7.5 \%$. Dilution of full-strength sea water (35\%) had no detectable effect on shell weight down to $15 \%$. A further dilution produced a decrease in final shell weight, which coincided with a smaller final shell length. Starting from an initial shell length of $7.6 \pm 0.2 \mathrm{~mm}$, juvenile mussels kept in 7.5 and $10 \%$ grew to a length of $10.6 \pm 1$ and $13.6 \pm 0.6 \mathrm{~mm}$. The final average in 15 to $35 \%$ was $15.1 \pm 1.3 \mathrm{~mm}$. Length-normalized shell weight (Table 3) indicated that shell thickness was rather uniform in all salinities.

\section{Discussion}

Considerable interaction of salinity on Cd accumulation by molluscs has frequently been reported, low salinity promoting experimental uptake rates (reviews: Phillips 1980, Eisler 1981). Higher soft tissue Cd concentrations in mussels from the Baltic Sea are well documented (Karbe et al. 1977, Phillips 1977. Theede et al. 1979). Comparative investigations of mussels from clean shorelines have shown North Sea samples (mean salinity $30 \%$ ) to have less than half the $\mathrm{Cd}$ / shell-wt index of mussels from the Western Baltic (mean salinity $15 \%$; Fischer 1983). Dissolved Cd, however, has been reported to be almost the same in both areas (Kremling et al. 1979, Schmidt 1980, Sperling 1985).

A higher percentage of free $\mathrm{Cd}^{2+}$ in low salinity (cf.
Mantoura et al. 1978) has been considered for increased uptake rates by organisms subjected to large laboratory gradients, and for higher acute toxicity of Cd (Sunda et al. 1978, Engel \& Fowler 1979). Competitive interactions with calcium have been discussed (Westernhagen et al. 1974, Wright 1977, Lehnberg \& Theede 1979). Phillips (1977) generalized, from field observations, that availability of $\mathrm{Cd}$ to mussels was greater in the Baltic. He suggested that only mussels from the same salinity should be compared.

In general, contaminant concentrations of aquatic environments are given in terms of weight per volume. ( $\mu \mathrm{g} \mathrm{l}^{-1}$ ), without considering other dissolved components. Reducing salinity while keeping contaminant concentration constant therefore has the effect of increasing the contaminant amount in relation to natural sea-water salts. This alone could account for an effect of salinity on $\mathrm{Cd}$ accumulation in molluscs. To test this assumption, the experimental design maintained an equimolar relation of $\mathrm{Cd}$ and natural salts in a sequence of salinities. According to this specific laboratory situation the null-hypothesis was that no difference in $\mathrm{Cd}$ accumulation would be detected. With respect to $\mathrm{Cd}$ concentration of soft tissues, this was verified in the range of salinities between 10 and $35 \%$ (Fig. 4a).

When using shell weight as an independent variable in relation to $\mathrm{Cd}$ content of molluscs, influences of salinity on calcification must be considered. This study shows that the increment of shell weight is reduced when salinity falls below $15 \%$ (Table 3 ). Growth of soft tissues is less affected, and the CI increases. Consequently the relation between $\mathrm{Cd}$ in soft tissues and (inhibited) shell weight is higher in mussels from the lower end of the salinity range.

Correction factors for direct comparisons of mussel watch data from different salinities can be derived from Fig. 5. Measured Cd/shell-wt indices were divided by experimental Cd concentrations (cf. Fig. 4). Hence, recalculated $\mathrm{Cd} / \mathrm{shell}-\mathrm{wt}$ indices relate to 


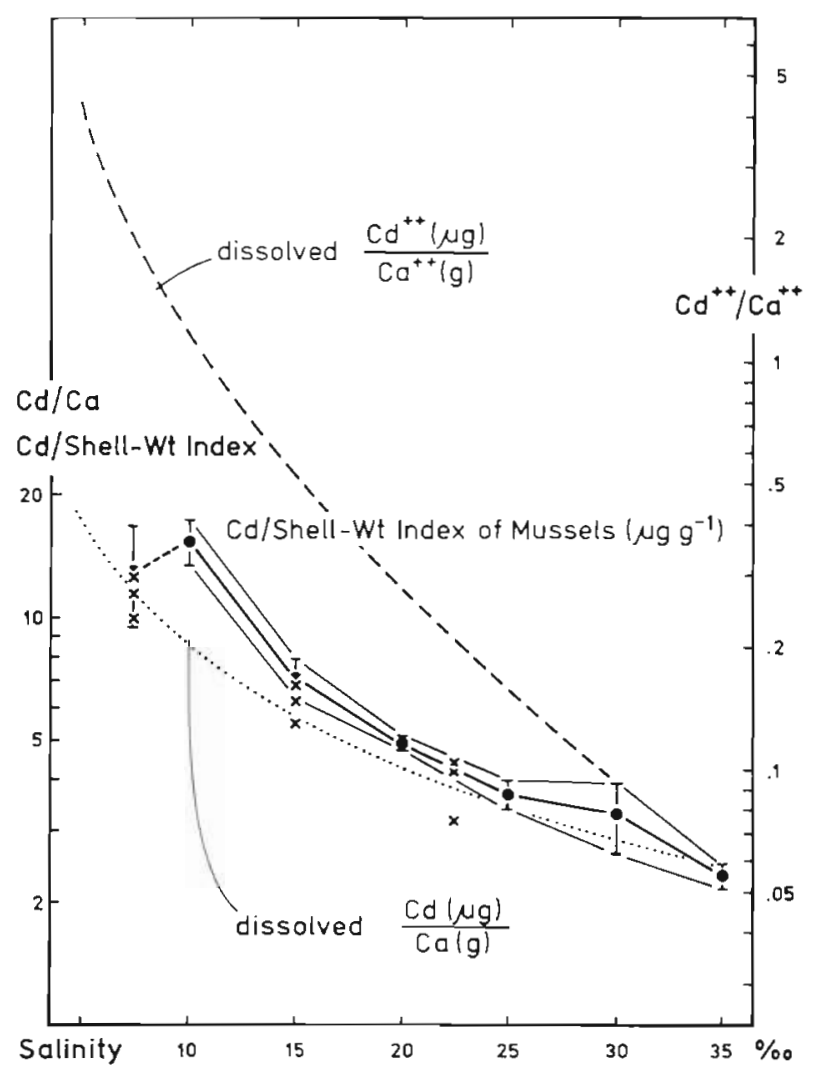

Fig. 5. Mytilus edulis. Influence of salinity on $\mathrm{Cd} /$ shell-wt index. $\mathrm{Cd} / \mathrm{shell}$-wt index of mussels is determined by the concentrations of $\mathrm{Cd}$ and $\mathrm{Ca}$ in the water (bars, dotted line; left scale) rather than by free ions (broken line calculated after Mantoura et al. 1978; right scale). Bars: $95 \%$ confidence intervals of means, recalculated for $1 \mu \mathrm{g}^{-1}$ dissolved $\mathrm{Cd}$; $\mathrm{x}$ : data from experiments with $1 \mu \mathrm{g} \mathrm{l}^{-1}$ dissolved $\mathrm{Cd}$

$1 \mu \mathrm{g} \mathrm{l}^{-1}$ dissolved $\mathrm{Cd}$ in all salinities. Experiments actually conducted with this concentration produced similar results (Fig. 5, x). In salinities between 15 and $35 \%$ the $\mathrm{Cd} /$ shell-wt index is close to the ratio of dissolved $\mathrm{Cd} / \mathrm{Ca}$ (dotted line). Obviously the concentrations of dissolved metals determine the balance of $\mathrm{Cd}$ and $\mathrm{Ca}$ in mussels when grown in a physiological steady-state with their environment. The free ions (Fig. 5, broken line; calculated according to Mantoura et al. 1978) may dominate acute toxicity of metals and influx rates (cf. Sunda et al. 1978, Engel \& Fowler 1979) when organisms are subjected to high concentrations of contaminants in short-term tests

Some tentative calculations may illustrate the capacity of mussels to concentrate $\mathrm{Cd}$ and $\mathrm{Ca}$ from the water. One 1 of full-strength sea water contains approximately $400 \mathrm{mg} \mathrm{Ca}$, which is incorporated to produce $1 \mathrm{~g}$ $\mathrm{CaCO}_{3}$ in the shells. A CI of $14 \%$ (Fig. 4) means that a shell of $1 \mathrm{~g}$ covers a soft body of $170 \mathrm{mg}$ dry weight, or roughly $1 \mathrm{~g}$ wet weight. One can conclude from these relations that mussels concentrate Ca from fullstrength sea water by a factor of approximately 1000.
The concentration factor $(\mathrm{CF})$ of $\mathrm{Cd}$ in soft tissues is roughly 2500 , corresponding to a $\mathrm{Cd} /$ shell-wt index of $2.3 \pm 0.2 \mu \mathrm{g} \mathrm{g}^{-1}$ of mussels grown in $35 \%$ salinity and $1 \mu \mathrm{g}^{-1}$ dissolved Cd (Fig. 5). The CFs of $\mathrm{Cd}$ and $\mathrm{Ca}$ increase in lower salinity. It should be noted that the above estimates include reference to soft tissue weight, which is rather variable in field populations. Consequently, derived variables such as $\mathrm{CI}, \mathrm{CF}$, and $\mathrm{Cd}$ concentration of soft tissues fluctuate as well. Though being modified by reduced shell growth in lower salinity, the $\mathrm{Cd} /$ shell-wt index should be preferred for the biological monitoring of $\mathrm{Cd}$ in coastal waters. Salinity must be recorded to allow comparisons.

Compared to the impressive amount of information on the effects of temperature, relatively little is known about salinity (cf. Kinne 1971, review). Juvenile blue mussels produced smaller shells in salinities below $15 \%$, confirming the well-established reduction of size in suboptimal salinities (cf. Remane 1940). Disproportional growth of meat resulted in well-developed mantle tissues of small $(10 \mathrm{~mm})$ individuals from $7.5 \%$, similar to ripe adults just before spawning. It was interesting to note that shell thickness (in terms of length-normalized shell weight) obviously was not markedly influenced by dilution of seawater down to $10 \%$ (Table 3). This is in contrast to Schlieper \& Kowalski (1957) who attributed different shell thickness of field-collected mussels to the influence of salinity. Newcombe \& Kessler (1936) mentioned that difference in shell thickness (of soft shell clams Mya arenaria) 'seems not to be necessarily related to salinity. Heavier shell may be a natural concomitant of increased size in optimum salinities rather than a relation per se of heavier shell to salinity' (see also Eisma 1965, on Cardium edule). The experimental results reported here indicate that shell proportions of juvenile Mytilus edulis are relatively independent over a wide range of salinities. Between 10 and $35 \%$, shell thickness of field-collected mussels may be determined by other environmental variables, such as tidal exposure (Baird \& Drinnan 1957), wave action (Harger 1970), or nutrition (Havinga 1929, Winter 1974). Further investigation is needed, the more so since recording shell weight of mussels has been adopted internationally for contaminant monitoring programmes (ICES 1985, BMI 1986).

\section{Dissolved oxygen}

Experimental techniques

A sequence of experimental dissolved oxygen (DO) levels was set up using an initial degassing step at different temperatures up to $70^{\circ} \mathrm{C}$. On its way to the 


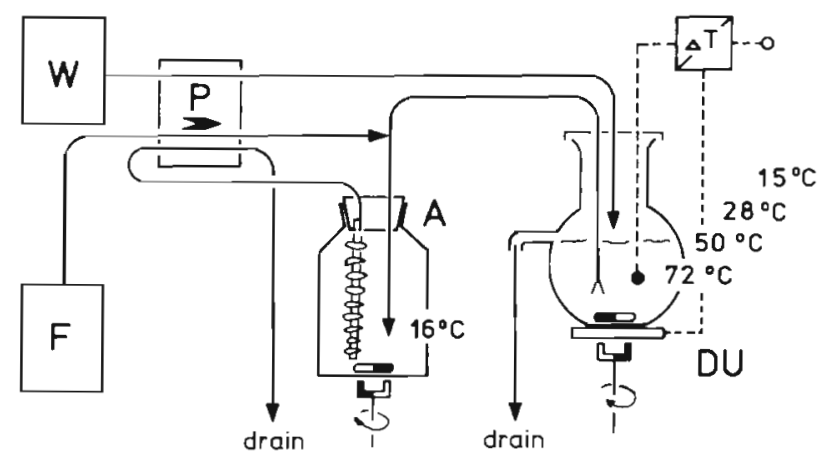

Fig. 6. Flow-through system for testing effects of oxygen deficiency. W: water; F: feed algae; P: peristaltic pump; DU: series of thermoregulated $(\Delta T)$ degassing units; $A$ : series of gas-tight aquaria

flow-through aquaria the water was cooled to the experimental temperature of $16^{\circ} \mathrm{C}$. This physical process resulted in a graded series of oxygen deficiencies according to the degassing temperatures (Fig. 6). DO was determined at 7 to $14 \mathrm{~d}$ intervals by the Winkler method. Measured data varied by $\pm 0.5 \mathrm{ml} \mathrm{l}^{-1}$. They were approximately $1.5 \mathrm{ml} \mathrm{l}^{-1}$ lower than the equilibrium in the degassing units, attributable to the oxygen demand of mussels, microorganism fouling of the walls, and organic debris.

Stoppered glass bottles with a magnetic stirrer were used as flow-through aquaria. All tubing was made from oxygen-tight material (Tygon ${ }^{\circledR}$ and stainless steel). One aquarium was aerated as a control. The experimental water was initially heat-sterilized and reaerated before being delivered to the thermal degassing devices.

Routine operations included determination of salinity $(15.2 \pm 0.2 \%)$, temperature $\left(16.2 \pm 0.2{ }^{\circ} \mathrm{C}\right)$, and $\mathrm{pH}$ $(7.7 \pm 0.1)$. These environmental variables could have been influenced by degassing of the water at different temperatures, but no such differences were recorded.

\section{Results}

\section{Cadmium balance}

Cd concentration of soft tissues. Chemical analysis of soft tissues showed that differences of $\mathrm{Cd}$ concentration were insignificant in mussels grown at DO levels between 2.5 and $6.5 \mathrm{ml} \mathrm{l}^{-1}$ (Fig. 7). The mean value was $63 \pm 10 \mu \mathrm{g} \mathrm{g}^{-1}$.

Condition index. The mean physical condition was $9.6 \pm 1.9 \%$ meat of total dry weight. In DO concentrations below $3 \mathrm{ml} \mathrm{l}^{-1}$ there was a tendency towards lower $\mathrm{Cl}$ values, but this observation was not statistically significant due to substantial variability at the lowest DO level tested $\left(1.5 \mathrm{ml} \mathrm{l}^{-1}\right)$.

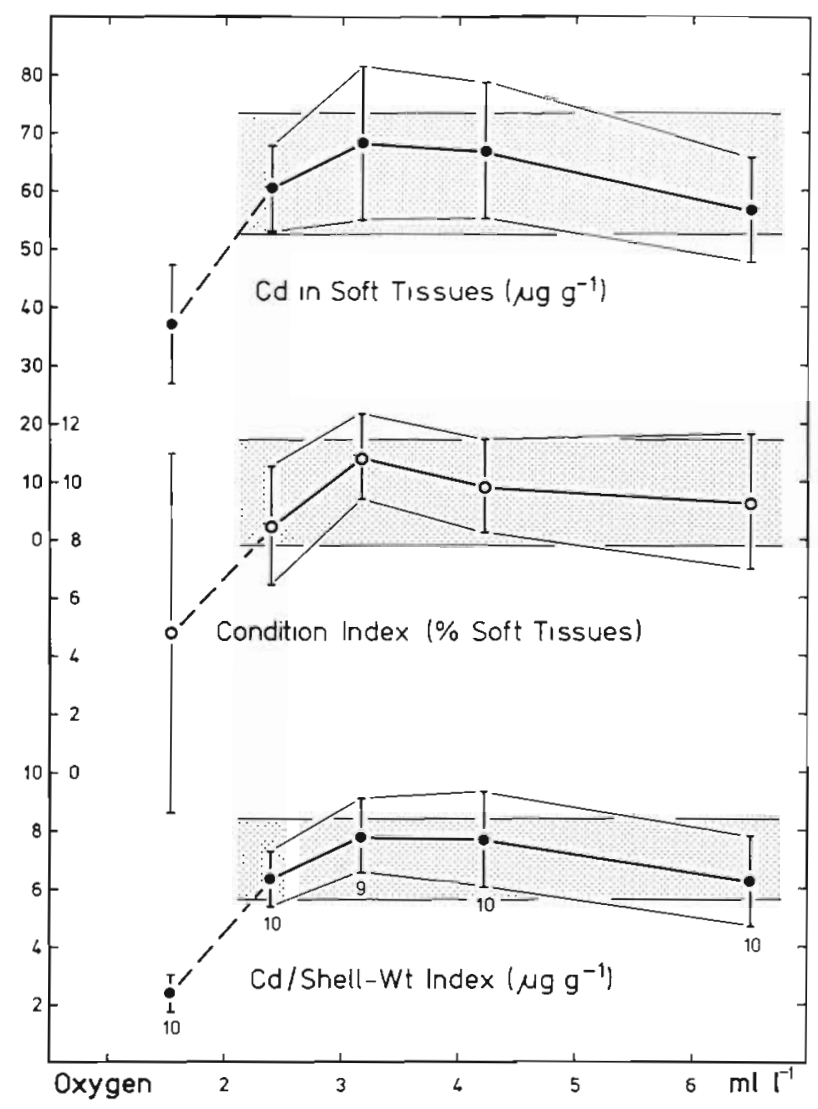

Fig. 7. Mytilus eduls. Influence of dissolved oxygen on $\mathrm{Cd}$

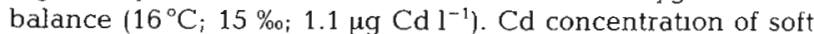
tissues, condition index, and $\mathrm{Cd} /$ shell-wt index are independent of dissolved oxygen between 2.5 and $6.5 \mathrm{ml} \mathrm{l}^{-1}$ Inhibltion of Cd accumulation occurred in the lowest experimental oxygen level. Bars: $95 \%$ confidence intervals of means; shaded: common arithmetic means

Cd/shell-wt index. There were no signuficant differences in the $\mathrm{Cd} /$ shell-wet indices of mussels grown at DO levels between 2.5 and $6.5 \mathrm{ml} \mathrm{l}^{-1}$. The mean value was $7.0 \pm 1.4 \mu \mathrm{g} \mathrm{g}^{-1}$.

Inconsistency. In mussels from the lowest DO level tested the uptake of $\mathrm{Cd}$ was significantly reduced as indicated by lower $\mathrm{Cd}$ concentration of soft tissues and lower $\mathrm{Cd} /$ shell-wt index.

\section{Growth and performance}

The flow-through experiment was conducted over a period of $20 \mathrm{wk}$. It was terminated when the controls had grown by a factor of 4.5 ; growth was reduced at lower DO levels. Calculations of expenmental increments showed that there had been virtually no growth of soft tissues at $1.5 \mathrm{ml} \mathrm{l}^{-1}$ DO (Table 4). Growth of shells, however, was by a factor of 1.5. This resulted in a lower CI of mussels from this lowest expenmental DO level (Fig. 7). Besides that, growth of meat and 
Table 4. Mytilus edulis. Influence of dissolved oxygen on growth in a $20 \mathrm{wk}$ experiment. Growth gradually declines with lower oxygen. A steep decrease of growth occurred below $2 \mathrm{ml} \mathrm{l}^{-1}$ DO (95\% confidence intervals of means)

\begin{tabular}{|c|c|c|c|c|c|}
\hline & $\begin{array}{r}1.54 \\
\pm \quad 36\end{array}$ & $\begin{array}{r}2.39 \\
\pm \quad 43\end{array}$ & $\begin{array}{c}\mathrm{O}(\mathrm{ml} \mathrm{l} \\
\mathrm{n}=15 \\
3.17 \\
\pm \quad .49\end{array}$ & $\begin{array}{r}4.23 \\
\pm \quad .54\end{array}$ & $\begin{array}{r}6.50 \\
+\quad 47\end{array}$ \\
\hline $\begin{array}{l}\text { Meat-Wt/Meat-W } \mathrm{t}_{0} \\
\mathrm{n}=10\end{array}$ & $\begin{array}{r}1.06 \\
\pm \quad 28\end{array}$ & $\begin{array}{r}2.99 \\
+\quad .56\end{array}$ & $\begin{array}{r}3.71 \\
\pm \quad 73\end{array}$ & $\begin{array}{r}3.88 \\
\pm \quad .61\end{array}$ & $\begin{array}{r}4.65 \\
\pm 1.37\end{array}$ \\
\hline $\begin{array}{l}\text { Shell-Wt/Shell-W } \mathrm{t}_{0} \\
\mathrm{n}=10\end{array}$ & $\begin{array}{r}1.53 \\
+\quad 28\end{array}$ & $\begin{array}{r}2.74 \\
\pm \quad .38\end{array}$ & $\begin{array}{r}3.07 \\
+\quad 51\end{array}$ & $\begin{array}{r}3.36 \\
+\quad 31\end{array}$ & $\begin{array}{r}4.15 \\
+1.39\end{array}$ \\
\hline
\end{tabular}

shells occurred at about the same rate, with a gradual increase of growth at higher DO levels. The largest experimental increment was by a factor of approximately 4.5 in air-saturated seawater. This corresponds to a growth constant of $0.0107 \pm 0.0022$, or a daily growth of $1.1 \pm 0.2 \%$ of actual weight.

\section{Discussion}

Oxygen deficiency is a regular seasonal phenomenon in semi-enclosed ecosystems such as the Limfjord (Jørgensen 1980) and the bays of SW Kieler Bucht (Krey et al. 1978, Gerlach 1984). In September 1981 extensive water masses in Kieler Bucht were devoid of oxygen and saturated with hydrogen sulfide (Ehrhardt \& Wenk 1984). Severe mortality of benthic fauna was recorded (Weigelt 1985). Blue mussels have been shown to resist hydrogen sulfide for several weeks (Theede et al. 1969). Following the 1981 period of anoxia a considerably lower $\mathrm{Cd}$ /shell-wt index was observed in mussels from the affected area (Fischer 1983). This has been interpreted as a result of a lower availability to biota of $\mathrm{Cd}$ after the formation of cadmium-sulfur compounds (Fischer 1984, cf. Kremling 1983).

In most cases hydrogen sulfide is confined to bottom water. Mussels, living in the upper water layer, may be frequently subjected to lowered oxygen levels. This could affect their ability to reflect environmental levels of dissolved cadmium. The experiment has shown that $\mathrm{Cd} /$ shell-wt indices were independent of DO between 2.5 and $6.5 \mathrm{ml} \mathrm{l}^{-1}$. Irrespective of $\mathrm{DO}$ in the tested range, lower $\mathrm{Cd}$ /shell-wt indices of mussels indicate lower concentrations of (biologically available) $\mathrm{Cd}$ in the water.

Compared to the controls, a lower growth rate of juvenile mussels was recorded at decreased oxygen concentrations. This is in accordance with experimental observations on fish (cf. Davis 1975, review) and clams (Neuhoff 1983), and with field data on mussels (Riisgård \& Poulsen 1981). The growth rate of controls in air-saturated water was only $1 / 3$ the value observed in the experiments on temperature and salinity. It is not clear why. The tests were conducted in winter. Pretreatment of the experimental water with heat may have denatured seasonally low levels of dissolved organic matter. Such substances may contribute significantly to the nutrition of marine invertebrates including mussels (Siebers \& Winkler 1984). In other experiments conducted in winter (unpubl.) mussels also grew more slowly, but retardation was less than reported here.

\section{Comparative evaluation}

Inconsistent results observed at the lowest experimental levels of temperature, salinity, and dissolved oxygen are not discussed here. They require consideration in a methodological context and will be dealt with in a subsequent section. Observations on $\mathrm{Cd}$ concentration and $\mathrm{CI}$ from different experiments cannot be compared because growth conditions were not the same. Comparisons must be restricted to the $\mathrm{Cd} / \mathrm{shell}$ wt index.

\section{Consolidation of experimental data}

The average $\mathrm{Cd} /$ shell-wt indices observed in the experiments on effects of temperature (Fig. 2b, shaded) and DO (Fig. 7, shaded) relate to Cd concentration of approximately $1.1 \mathrm{\mu g} \mathrm{l}^{-1}$ in a salinity of $15 \%$. The mean $\mathrm{Cd}$ /shell-wt index of mussels grown in different salinities relates to $1.7 \mathrm{\mu g} \mathrm{l}^{-1} \mathrm{Cd}$ in $15 \%$. Since the molar ratio of dissolved $\mathrm{Cd}$ and seawater salts was constant, this value represents salinities between 15 and $30 \%$ (Fig. 4b, shaded). Growth experiments with a graded series of $\mathrm{Cd}$ concentrations have shown that $\mathrm{Cd}$ accumulation by mussels is proportional to environmental levels (unpubl. data). Anticipatively, the $\mathrm{Cd} /$ shell-wt indices observed in the experiments reported here are corrected for the same concentration of $1 \mu \mathrm{g}$ $\mathrm{I}^{-1}$ dissolved $\mathrm{Cd}$, dividing mean values by the respective experimental Cd concentrations (Table 5). 
Table 5. Mytilus edulis. Laboratory observations of $\mathrm{Cd} /$ shell-wt indices from 3 cultivation experiments. Correcting measured data for the same salinity $(15 \%)$ and for the same Cd concentration $\left(1 \mu \mathrm{g} \mathrm{l}^{-1}\right)$ results in a common overall mean (arithmetic means of $95 \%$ confidence intervals)

\begin{tabular}{|c|c|c|c|}
\hline & $\begin{array}{c}\text { Temperature } \\
7-25^{\circ} \mathrm{C}\end{array}$ & $\begin{array}{l}\text { imental va } \\
\text { Salinity } \\
15-30 \%\end{array}$ & $\begin{array}{c}\text { Oxygen } \\
2.5-6.5 \mathrm{ml} \mathrm{l}^{-1}\end{array}$ \\
\hline Dissolved $\mathrm{Cd}\left(\mu \mathrm{g}^{-1}\right)$ in $15 \%$ salinity & 1.1 & 1.7 & 1.1 \\
\hline $\mathrm{Cd} /$ shell-wt index $\left(\mu \mathrm{g} \mathrm{g}^{-1}\right)$ & $\begin{array}{r}8.2 \\
\pm 1.1\end{array}$ & $\begin{array}{r}11.3 \\
+\quad 1.2\end{array}$ & $\begin{array}{r}7.0 \\
\pm 1.4\end{array}$ \\
\hline $\begin{array}{l}\mathrm{Cd} / \text { shell-wt index }\left(\mu \mathrm{g} \mathrm{g}^{-1}\right) \text { corr. for } 1.0 \mu \mathrm{l}^{-1} \mathrm{Cd} \\
\text { in } 15 \% \text { salinity }\end{array}$ & $\begin{array}{r}7.5 \\
\pm 1.0\end{array}$ & $\begin{array}{r}6.5 \\
\pm \quad 0.7\end{array}$ & $\begin{array}{r}6.4 \\
\pm 1.4\end{array}$ \\
\hline Overall mean & & $\begin{array}{r}6.8 \\
\pm \quad 1.0\end{array}$ & \\
\hline
\end{tabular}

Differences of these calculated data are not significant. Therefore a Cd/shell-wt index of $6.8 \pm 1.0 \mu \mathrm{g} \mathrm{g}^{-1}$ can be used as an overall estimate for mussels grown in a salinity of $15 \%$ with $1.0 \mathrm{\mu g} \mathrm{l}^{-1} \mathrm{Cd}$. This value represents 13 experimental regimes of temperature, salinity, and dissolved oxygen. The $95 \%$ confidence interval corresponds to 9 to 10 individuals analysed in a sample.

\section{Field correlates}

Are the experimental results consistent with $\mathrm{Cd} /$ shell-wt indices of mussels grown in their natural habitat? Two sets of data can be used for comparative calculations (Table 6). (1) Mussels (Fischer 1983, and unpubl. data) and water (Sperling 1985) were repeatedly sampled at the same time in the German Wadden Sea NE of the island of Sylt (salinity $30 \%$ ). (2) Mussels were sampled in the Western Baltic Sea in November 1980 (salinity 18\%). Mussel watch results can be related to water analyses of Kremling et al. (1979), assuming a relative constancy over the years according to measured data and a comparable hydrographic situation (cf. Fischer 1983). The sequence of calculations is: correcting $\mathrm{Cd} /$ shell-wt indices for a salinity of $15 \%$ (this study), and dividing them by data of dissolved $\mathrm{Cd}$ reported by others. This results in a hypothetical $\mathrm{Cd} /$ shell-wt index of field-collected mussels if salinity had been $15 \%$ and if dissolved $\mathrm{Cd}$ had been $1 \mu \mathrm{g} \mathrm{I}^{-1}$. These data are close to the overall mean of experimental results relating to the same salinity and $\mathrm{Cd}$ concentration.

Table 6. Mytilus edulis. Cd/shell-wt index of field samples in relation to dissolved Cd. Correcting field data for a salinity of $15 \%$ and a $\mathrm{Cd}$ concentration of $\mu \mathrm{l}^{-1}$ produces hypothetical values of field data which are close to experimental mean values $195 \%$ confidence intervals of means)

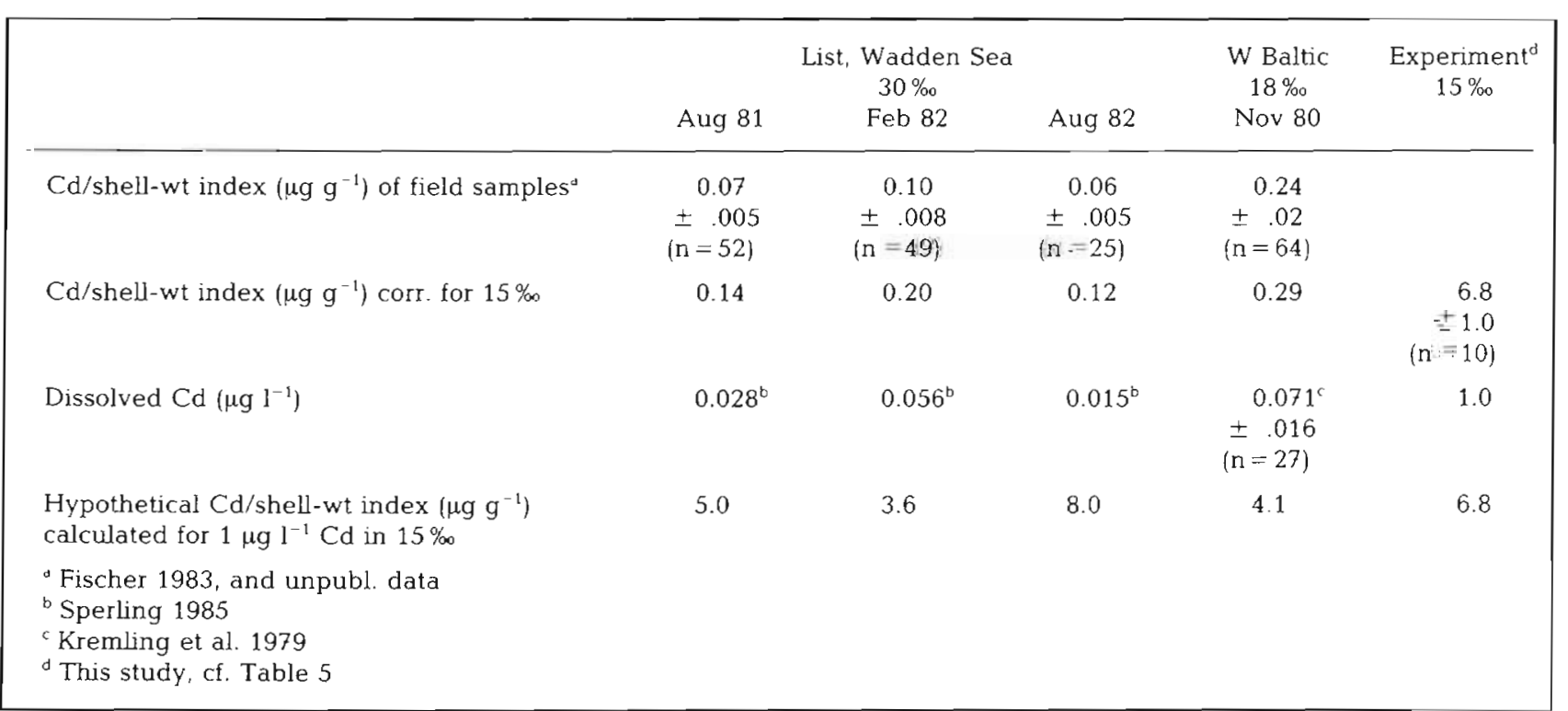




\section{GENERAL CONSIDERATIONS}

\section{Scaling of experimental studies}

The high variability found in natural environments presents major difficulties in determining the influence of specific field variables on response variables. Therefore it was felt impossible to derive the influence of temperature, salinity, and dissolved oxygen on the Cd balance of mussels from comparative field investigations. Experimental physiologists and toxicologists are aware of the need to perform long-term studies with low contaminant levels if ecologically valid results are sought. Regarding the time scales involved in longeval species such as mussels, however, studies on tissue residues have been considered to be most difficult (cf. Perkins 1979).

The 'normal' condition of molluscs in the field is growth in a physiological steady-state with respect to the environment. Conducting controlled cultivation experiments with a low Cd concentration was considered to be an adequate laboratory approach. When choosing a time scale in relation to growth, such experiments may be regarded as being long-termed if mussels had achieved a major portion of their weight in a laboratory environment. The use of juveniles is recommended for 3 reasons. (1) Juveniles have a higher growth rate than adults (review: Jörgensen 1976), which reduces duration of experiments. (2) Cultivating juveniles reduces the volumes of clean sea water, especially when conducting flow-through experiments, and of feed algae cultures (filtration rates: Winter 1978, review). (3) Initial uptake of contaminants by juveniles within a (small) laboratory gradient is faster than in larger specimens (cf. SchulzBaldes 1974, Cunningham \& Tripp 1975). Growth, however, is not an absolute scale in relation to physiological functions. High temperature, for example, accelerates metabolic turnover, but growth decreases in temperatures higher than the optimum (Table 2). In the case of salinity, mussels may need a prolonged period to achieve a new physiological steady state if changes exceeded their normal range of 10 to $30 \%$ or more (cf. Kinne 1971, review). If mussels failed to grow, experiments were short-termed with respect to a time scale in relation to growth, and results might be less reliable. Organismic properties and needs must be considered when using biological indicators in contaminant monitoring and related research.

\section{Growth and cadmium accumulation}

In contrast to the consistency of results within the study (Table 5) and in relation to field correlates (Table
6), accumulation of $\mathrm{Cd}$ was significantly reduced in the lowest experimental levels of temperature (Fig. 2), salinity (Fig. 4), and dissolved oxygen (Fig. 7). Growth rates were also lower (Tables $2,3 \& 4$ ). Obviously the life functions of $\mathrm{Cd}$ accumulation and growth are linked to each other. Both were seriously impaired when mussels were subjected to unfavourable conditions. There is a corresponding observation on oysters Crassostrea virginica: uptake of Cd was confined to temperatures higher than $6^{\circ} \mathrm{C}$ (Zaroogian \& Cheer 1976), or the growth season.

Accumulation of $\mathrm{Cd}$ is a normal biochemical function (cf. Nordberg \& Kojima 1979, review). This implies a 'normal' metabolic state, which is indicated by growth of mussels. If life functions were retarded, e.g. by low levels of temperature, salinity, and dissolved oxygen, or by toxic levels of other metals (e.g. Zn; unpubl.), uptake of $\mathrm{Cd}$ from the environment was also reduced. The dependency of growth rates on age of mussels (review: Jorgensen 1976) may be responsible for low uptake rates of Cd from contaminated environments by large (old) individuals: a balanced state of mussels in relation to $\mathrm{Cd}$ has been observed neither in laboratory studies, even with low Cd levels (e.g. Jackim et al. 1977, Westernhagen et al. 1978), nor in field transplant experiments (de Kock 1983).

In this context adequate nutrition might be mentioned as a prerequisite of growth in animals. If food was inadequate in composition, the accumulation of Cd could be affected (as demonstrated with rats; Whanger \& Oh 1979). The observation of higher uptake rates of $\mathrm{Cd}$ by mussels when given food (cf. Janssen \& Scholz 1979, Köhler \& Riisgård 1982, Borchardt 1985) may be interpreted considering this aspect.

\section{Importance of growth in the mussel watch concept}

A low reactivity of mussels to environmental changes is neccessary to dampen environmental oscillations, but it appears to be contradictive to the concept of using mussels as indicators of average environmental levels including their changes.

Biological indicators have been defined as 'time integrators' of variable contaminant levels (cf. Phillips 1980, review), a suitable view considering the cumulative storage of $\mathrm{Cd}$ (and of other contaminants with long biological half lives) in the soft tissues of molluscs, and of Ca (as carbonate) in the shells. Changes of environmental $\mathrm{Cd}$ concentration influence the amount of further additions to the $\mathrm{Cd}$ body burden. Theoretically, a new equilibrated $\mathrm{Cd} /$ shell-wt index could never be achieved. An approximation, however, is possible, depending on the quantity of $\mathrm{Cd}$ and $\mathrm{Ca}$ accumulated under changed conditions. 
The consistency of results observed in this study suggests that a balanced state could have been attained. At present it is not possible, however, to substantiate a suggestion how long mussels should have grown in a new environment to provide reliable information on $\mathrm{Cd}$ contamination. A factor of 1.5 by shell length, or 3 to 4 by weight, in a normal range of environmental variables may be regarded as a tentative estimate. In any case weight increments should be as high as possible to increase significance of results.

For this principle reason, fast-growing juveniles are recommended when conducting laboratory studies on cumulative contaminants and molluscs, or performing field transplant experiments. The mussel watch concept implies growth in the environment of concern as an essential methodological aspect, both in research and field work.

Acknowledgements. This study was performed while the author was sponsored by the Umweltbundesamt (UBA). Thanks are due to Prof. $H$. Theede for granting full scope, and for stimulating discussions. Technical assistance was by Monika Westphal. Financial support: UBA F\&E Vorhaben Wasser 10607033 to $\mathrm{H}$. Theede.

\section{LITERATURE CITED}

Almada-Villela, P. C., Davenport, J., Gruffydd, L. D. (1982) The effects of temperature on the shell growth of young Mytilus edulis. J. exp. mar. Biol. Ecol. 59: 275-288

Baird, R. H., Drinnan, R. E. (1957). The ratio of shell to meat in Mytilus as a function of tidal exposure. J. Cons perm. int. Explor. Mer 22: 329-336

Bayne, B. L., Thompson, R. J., Widdows, J. (1973). Some effects of temperature and food on the rate of oxygen consumption by Mytilus edulis L. In: Wieser, W. (ed.) Effects of temperature on ectothermic organisms. Springer, Berlin, p. 181-193

Betz, M. (1977). Investigations on the simultaneous uptake and release of mercury by Dunaliella tertiolecta. Mar. Biol. 41: 89-97

BMI (1986). Contribution of the Federal Republic of Germany to the joint monitoring programme of the Oslo and Paris commissions. Working programme 1986-1995. Der Bundesminister des Inneren U III $4-520226 / 3$ - v. 31. 1. 86 , Anlage 2. Bonn, p. $1-38$

Bøhle, B. (1972). Effects of adaptation to reduced salinity on filtration activity and growth of mussels (Mytilus edulis L.). J. exp. mar. Biol. Ecol. 10: 41-47

Borchardt, T (1985). Relationship between carbon and cadmium uptake in Mytilus edulis. Mar. Biol. 85: 233-244

Boje, R. (1965). Die Bedeutung von Nahrungsfaktoren für das Wachstum von Mytilus edulis L. in der Kieler Förde und im Nord-Ostsee-Kanal. Kieler Meeresforsch. 21: 81-100

Bryan, G. W. (1980). Recent trends in research on heavy-metal contamination in the sea. Helgoländer Meeresunters. 33 : $6-25$

Cossa, D., Bourget, E., Piuze, J. (1979). Sexual maturation as a source of vanation in the relationship between cadmium concentration and body weight of Mytilus edulis L. Mar. Pollut. Bull. 10: 174-176
Coulthard, H. S. (1929). Growth of the sea mussel. Contr. Can. Biol. Fisher. 4: 123-136

Cunningham, P. A., Tripp, M. R. (1975). Factors affecting accumulation and removal of mercury from tissues of the American oyster Crassostrea virginica. Mar. Biol. 31: $311-320$

Davis, J. C. (1975). Minimal dissolved oxygen requirements of aquatic life with emphasis on Canadian species: a review. J. Fish. Res. Bd Can. 32: 2295-2332

de Kock, W C. (1983). Accumulation of cadmium and polychlorinated biphenyls by Mytilus edulis transplanted from pristine water into pollution gradients. Can. J. Fish. Aquat. Sci. 40 Supp. 2: 282-294

Ehrhardt, M., Wenck, A. (1984). Wind pattern and hydrogen sulfide in shallow waters of the Western Baltic Sea, a cause and effect relationship? Meeresforschung 30: $101-110$

Eisler, R. (1981). Trace metal concentrations in marine organisms. Pergamon Press, New York

Eisma, D. (1965). Shell characteristics of Cardium edule L. as an indicator of salinity. Neth. J. Sea Res. 2: 493-540

Engel, D. W., Fowler, B. A. (1979). Factors influencing cadmium accumulation and its toxicity to marine organisms. Environ. Health Perspect. 28: 81-88

Fischer, H. (1983). Shell weight as an independent variable in relation to cadmium content of molluscs. Mar. Ecol. Prog. Ser. 12: $59-75$

Fischer, H. (1984). Cadmium body burden/shell weight of mussels: A precise index for environmental monitoring. Coun. Meet. int. Coun. Explor. Sea C.M.-ICES/E: 41, 1-19

Gerlach, S. A. (ed.) (1984). Oxygen depletion 1980-1983 in coastal waters of the Federal Republic of Germany. Ber Inst. Meeresk. Univ. Kiel 130: 1-87

Goldberg, E. D. (1975). The mussel watch - a first step in global marine monitoring. Mar Pollut. Bull. 6: 111

Goldberg, E. D., Koide, M., Hodge, V., Flegal, A. R., Martin, J. (1983). U. S. mussel watch: $1977-1978$ results on trace metals and radionuclides. Estuar. coast. Shelf. Sci. 16: 69-93

Harger, J. R. E. (1970). The effect of wave impact on some aspects of the biology of sea mussels. Veliger 12: 401-414

Harger, J. R. E. (1971). Variation and relative niche' size in the sea mussel Mytilus edulis in association with Mytilus californianus. Veliger 14: 275-282

Havinga, B. (1929). Krebse und Weichtiere. In: Lübbert, H., Ehrenbaum, E. (ed.) Handbuch der Seefischerei Nordeuropas, Vol. III (2). Schweizerbart, Stuttgart, p. 1-147

ICES (1982). Guidelines to be followed for sample collection, preparation and analysis of fish and shellfish in the conduct of cooperative monitoring. ICES, Copenhagen

ICES (1985). Proces-verbal de la reunion 1984. ICES, Copenhagen

Jackim, E., Morrison, G., Steele, R. (1977). Effects of environmental factors on radiocadmium uptake by four species of marine bivalves. Mar. Biol. 40: 303-308

Janssen, H. H., Scholz, N. (1979). Uptake and cellular distribution of cadmium in Mytilus edulis. Mar. Biol. 55: 133-141

Jorgensen, B. B. (1980). Seasonal oxygen depletion in the bottom waters of a Danish fjord and its effects on the benthic community. Oikos 34: 68-76

Jörgensen, C. B. (1976). Growth efficiencies and factors controlling size in some mytilid bivalves, especially Mytilus edulis: A review and interpretation. Ophelia 15: 175-192

Karbe, L., Schnier, C., Siewers, H. O. (1977). Trace elements in mussels (Mytilus edulis) from coastal areas of the North Sea and the Baltic. Multielement analyses using instru- 
mental neutron activation analysis. J. radioanalyt. Chem. 37: $927-943$

Kinne, O. (1971). Salinity: Invertebrates. In: Kinne, O. (ed.) Marine ecology, Vol. I, Environmental tactors, Part 2. Wiley, London, p. 821-995

Köhler, K., Riisgård, H. U. (1982). Formation of metallothioneins in relation to accumulation of cadmium in the common mussel Mytilus edulis. Mar. Biol. 66: 53-58

Kremling, K. (1983). The behavior of $\mathrm{Zn}, \mathrm{Cd}, \mathrm{Cu}, \mathrm{Ni}, \mathrm{Co}, \mathrm{Fe}$, and $\mathrm{Mn}$ in anoxic Baltic waters. Mar chem. 13: 87-108

Kremling, K., Otto, C., Petersen, H. (1979). SpurenmetallUntersuchungen in den Förden der Kieler Bucht - Datenbericht von 1977/78. Ber. Inst. Meeresk. Univ. Kiel 66: $1-38$

Krey, J., Babenerd, B., Lenz, J. (1978). Beobachtungen zur Produktionsbiologie des Planktons in der Kieler Bucht: 1957-1975. I. Datenband. Ber. Inst. Meeresk. Univ. Kiel 54: $1-113$

Lehnberg, W., Theede, H. (1979). Kombinierte Wirkungen von Temperatur, Salzgehalt und Cadmium auf Entwicklung, Wachstum und Mortalität der Larven von Mytilus edulis aus der westlichen Ostsee. Helgoländer Meeresunters. 32: 179-199

Mann, R. (1979). Some biochemical and physiological aspects of growth and gametogenesis in Crassostrea gigas and Ostrea edulis grown at sustained elevated temperatures. J. mar. biol. Ass. U.K. 59: 95-110

Mann, R., Ryther, J. H. (1977). Growth of six species of bivalve molluscs in a waste recycling-aquaculture system. Aquaculture 11: 321-245

Mantoura, R. F. C., Dickson, A., Riley, J. P. (1978). The complexation of metals with humic materials in natural waters. Estuar. coast. Mar. Sci. 6: 387-408

Neuhoff, H.-G. (1983). Synergistic physiological effects of low copper and various oxygen concentrations on Macoma balthica. Mar. Biol. 77: 39 48

Newcombe, C. L., Kessler, H. (1936). Variations in growth indices of Mya arenaria L. on the Atlantic coast of North America. Ecology 17: 429-443

Nordberg, M., Kojima, Y. (ed.) (1979). Metallothionein and other low molecular weight metal-binding proteins. In: Kägi, J. H. R., Nordberg, M. (ed.) Metallothionein. Birkhäuser, Basel, p. 41-124

Orren, M. J., Eagle, G. A., Hennig, H. F.-K. O., Green, A. (1980). Variation in trace metal content of the mussel Choromytilus meridionalis (Kr.) with season and sex. Mar. Pollut. Bull. 11: 253-257

Perkins, E. J. (1979). The need for sublethal studies. Phil. Trans. R. Soc. B. 286: 425-442

Phillips, D. J. H. (1976). The common mussel Mytulus edulis as an indicator of pollution by zinc, cadmium, lead and copper. I. Effects of environmental variables on uptake of metals. Mar. Biol. 38: 59-69

Phillips, D. J. H. (1977). The common mussel Mytilus edulis as an indicator of trace metals in Scandinavian waters. II. Zinc and cadmium. Mar. Biol. 43: 283-292

Phillips, D. J. H. (1980). Quantitative aquatic biological indicators. Applied Science Publishers, London

Remane, A. (1940). Einführung in die zoologische Okologie der Nord- und Ostsee. In: Grimpe, G., Wagler, E. (ed.) Die Tierwelt der Nord- und Ostsee, Vol. Ia. Akademische Verlagsgesellschaft, Leipzig, p. 1-238

Richards, O. W. (1946). Comparative growth rates of Mytilus californianus at La Jolla, California and Mytilus edulis at Woods Hole, Massachusetts. Ecology 27: 370-372

Riisgård, H. U., Poulsen, E. (1981). Growth of Mytilus edulis in net bags transferred to different localities in a eutrophicated Danish fjord. Mar. Pollut. Bull. 12: 272-276

Riisgård, H. U., Randløv, A., Kristensen, P. S. (1980). Rates of water processing, oxygen consumption and efficiency of particle retention in veligers and young post-metamorphic Mytilus edulis. Ophelia 19: 37-47

Schlieper, C., Kowalski, R. (1957). Weitere Untersuchungen zur ökologischen Physiologie der Miesmuschel Mytilus edulis L. Kieler Meeresforsch. 13: 3-10

Schmidt, D. (1980). Comparison of trace heavy-metals from monitoring in the German Bight and in the southwestern Baltic Sea. Helgoländer Meeresunters. 33: 576-586

Schulte, E. H. (1975). Influence of algal concentration and temperature on the filtration rate of Mytilus edulis. Mar. Biol. 30: 331-341

Schulz-Baldes, M. (1974). Lead uptake from sea water and food, and lead loss in the common mussel Mytilus edulis. Mar. Biol. 25: 179-193

Seed, R. (1968). Factors influencing shell shape in Mytilus edulis L. J. mar. biol. Ass. U.K. 48: 561-584

Siebers, D., Winkler, A. (1984). Amino-acid uptake by mussels, Mytilus edulis, from natural sea water in a flow through system. Helgoländer Meeresunters. 38: 189-199

Simkiss, K., Taylor, M. (1981). Cellular mechanisms of metal ion detoxification and some new indices of pollution. Aquat. Toxicol. 1: 279-290

Sperling, K.-R. (1985). Cadmiumbestimmungen in Küstenwasserproben aus der Deutschen Bucht. Vom Wasser 64 : $53-68$

Stephenson, M. D., Martin, M., Lange, S. E., Flegal, A. R. Martin, J. H. (1979). California mussel watch 1977-1978, Vol. II. Trace metal concentrations in the California mussel, Mytilus californianus. State Water Resources Control Board, Water quality monitoring report 79-22, Sacramento, p. 1-110

Sunda, W. G., Engel, D. W., Thuotte, R. M. (1978). Effect of chemical speciation on toxicity of cadmium to grass shrimp, Palaemonetes pugio: importance of free cadmium ion. Environ. Sci. Technol. 12: 409-413

Theede, H. (1963). Experimentelle Untersuchungen über die Filtrationsleistung der Miesmuschel Mytilus edulis L. Kieler Meresforsch. (Sonderh.) 19: 20-41

Theede, H., Andersson, I., Lehnberg, W. (1979). Cadmium in Mytilus edulis from German coastal waters. Meeresforschung 27: 147-155

Theede, H., Ponat, A., Hiroki, K., Schlieper, C. (1969). Studies on the resistance of marine bottom invertebrates to oxygen deficiency and hydrogen sulphide. Mar. Biol. 2: 325-337

Weigelt, M. (1985). Auswirkungen des Sauerstoffmangels 1981 auf das Makro-Zoobenthos und Bodenfische in der Kieler Bucht. Ber. Inst. Meeresk. Univ. Kiel 138: 1-122

Westernhagen, H. v., Dethlefsen, V., Rosenthal, H., Fürstenberg, G., Klinckmann, J. (1978). Fate and effect of cadmium in an experimental marine ecosystem. Helgoländer wiss. Meeresunters. 31: 471-484

Westernhagen, H. v., Rosenthal, H., Sperling, K.-R. (1974). Combined effects of cadmium and salinity on development and survival of herring eggs. Helgoländer wiss. Meeresunters. 26: 416-433

Whanger, P. D., Oh, S. H. (1979). Nutritional and environmental factors affecting metallothionein levels. In: Kägi, J. H. R., Nordberg, M. (ed.) Metallothionein. Birkhäuser, Basel, p. 281-291

Winter, J. E. (1974). Growth in Mytilus edulis using different types of food. Ber. dt. wiss. Komm. Meeresforsch. 23; $360-375$ 
Winter, J. E. (1978). A review on the knowledge of suspension-feeding in lamellibranchiate bivalves, with special reference to artificial aquaculture systems. Aquaculture 13: $1-33$

Witt, U., Koske, P. H., Kuhlmann, D., Lenz, J., Nellen, W. (1981). Production of Nannochloris spec. (Chlorophyceae) in large-scale outdoor tanks and its use as food organism in marine aquaculture. Aquaculture 23: 171-181
Wright, D. A. (1977). The effect of calcium on cadmium uptake by the shore crab Carcinus maenas. J. exp. Biol. 67: $163-173$

Zaroogian, G. E. (1980). Crassostrea virginica as an indicator of cadmium pollution. Mar. Biol. 58: 275-284

Zaroogian, G. E., Cheer, S. (1976). Accumulation of cadmium by the American oyster, Crassostrea virginica. Nature, Lond. 261: 408-410

This article was submitted to the editor; it was accepted for printing on June 16, 1986 